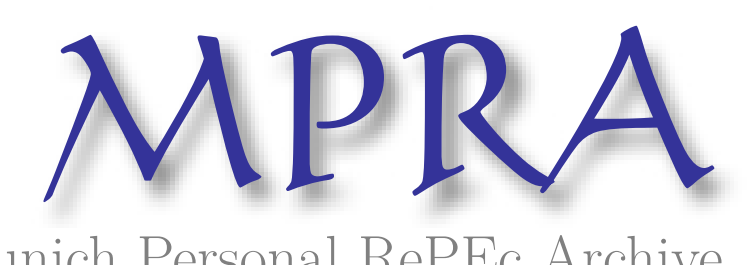

Munich Personal RePEc Archive

\title{
SOCIAL TRANSFERS AS A DETERMINANT OF INTRAHOUSEHOLD DISTRIBUTION: THE CASE OF CHILE
}

\author{
Cuesta, Jose \\ Institute of Social Studies
}

August 2004

Online at https://mpra.ub.uni-muenchen.de/12410/

MPRA Paper No. 12410, posted 31 Dec 2008 03:40 UTC 


\title{
SOCIAL TRANSFERS AS A DETERMINANT OF INTRAHOUSEHOLD \\ DISTRIBUTION: THE CASE OF CHILE
}

\author{
Dr. José Cuesta \\ Lecturer in Development Economics \\ Institute of Social Studies
}

\begin{abstract}
The effects of social transfers on individual participation and working hours are theoretically shown to differ for unitary and bargaining intrahousehold allocation models. This result is attributed to both the non-transferability of in-kind social transfers and differences in control of these transfers among household members. Using elasticities of social transfers on work effort (estimated through sample selection corrected participation probits and working hour $O L S$ ), new tests on intrahousehold allocation are developed for Chile. These tests strongly reject the unitary model and exogenous bargaining, accepting endogenous bargaining only among non-poor households. Poor households may use social incomes as investments for the future rather than for short-term strategic power relations.
\end{abstract}

JEL Classification: D1, Household Behavior; I38, Provision and Effects of Welfare Programs; J22, Time Allocation and Labor Supply.

Author: José Cuesta, PhD; Institute of Social Studies; Kortenaerkade 12; 2518 AX The Hague; The Netherlands. Tel. 003170426 0574; Fax. 003170426 0799; cuesta@iss.nl 


\title{
SOCIAL TRANSFERS AS A DETERMINANT OF INTRAHOUSEHOLD DISTRIBUTION: THE CASE OF CHILE
}

\author{
José Cuesta, Institute of Social Studies \\ Draft as of August 19
}

\section{INTRODUCTION}

Anthropological and sociological research has long shown the existence of intrahousehold gender discrimination, thus questioning the traditional unitary household allocation model. Gender differences affect power relations among household members as reported, for instance, in Blumberg (1988), Pahl (1989), and Jejeebhoy (1995). The proportion of individual income contributed to the household varies significantly by gender, as documented in places as different as India, Mexico, Cameroon or Honduras. Other manifestations of power imbalance include differences in consumption patterns (see e.g., Blumberg, 1988), domestic violence (e.g., Rao, 1997), fertility decisions and social activities (e.g., Casique, 2000).

Although economic research has, since the 1960s, developed alternative models of intrahousehold allocation to the unitary paradigm, ${ }^{1}$ intrahousehold relations still need to be further specified if they are to become relevant in policy-making. In spite of some developments in the characterization of these relations (described both as cooperative and non-cooperative games), they remain something of a 'black box'. There is, however, wide consensus on a number of factors affecting the bargaining power of household members - from dowries and pre-marriage assets, to human capital differentials among parents, or labor and social incomes. Beyond these general assumptions, this article explores the capacity of social transfers to test alternative intrahousehold allocation mechanisms. Conveniently — even without describing the

\footnotetext{
${ }^{1}$ See Leuthold (1968), Ashenfelter \& Heckman (1974), Schultz (1990), Browning et al (1994) for some classic references.
} 
dynamics of alternative mechanisms to the unitary model — the classical household model needs only be expanded minimally to allow for this empirical testing. In fact, distinctive properties associated with categories of social transfers make these incomes especially suitable for testing intrahousehold behavioral relations. Typically, the non-transferability of in-kind social transfers (in contrast with cash transfers) is shown theoretically to lead to differentiated impacts on the decision to work among household members. In designing bargaining tests which substantiate the distinctive nature of social transfers and their application to Chilean data, this paper casts new light on intrahousehold distribution.

The paper proceeds as follows. Section 2 builds some alternative exogenous and endogenous bargaining specifications of household behavior that predict alternative effects of social transfer categories on individual work decisions. It then details the estimating strategy that enables a proper testing of alternative intrahousehold behavior. Section 3 first estimates the value of Chilean social benefits transferred in 1996, before applying the estimating and testing strategy developed in section 2 to mid-1990s Chilean data.. Section 4 then assesses social transfer effects and conducts the proposed tests; Section 5 summarizes the findings of the paper.

\section{TESTING STRATEGIES}

\section{Modeling intrahousehold allocation behavior}

In addition to their properties of flexibility and tractability (Stern, 1984), the appeal of the quasi-homothetic Cobb-Douglas utility functions is the link forged between consumption, income, poverty, and individual labor supply (Chiappori, 1997). In 
contrast with previous analyses of poverty and labor supply, ${ }^{2}$ the decision to participate in work and (conditional on participation) the preferred number of working hours, are separated. As Killingsworth (1983) argues, even though both labor dimensions may result from the same decision process, their determinants do not need to have the same impacts on each decision. Cross-section evidence reported for Chile supports this characterization. ${ }^{3}$ What remains unclear from the research of intrahousehold allocation is how the different determinants interact towards a joint decision. However (and rather conveniently), the modeling of collective forms of household labor supply does not require much additional complexity for testing purposes: that is, testing whether social transfers are relevant determinants of bargaining vis-a-vis other factors and other intrahousehold allocation behaviors. In effect, labor decisions can be modeled using a similar maximization program to the unitary model, except that different categories of incomes now determine bargaining. In-kind incomes are no longer pooled together with the rest of cash incomes generated; that is, not every category of income is susceptible to redistribution within the household. Also, non-labor incomes may well have an impact on the generation of household resources. In as much as this impact is significant, non-labor primary incomes and social transfers act as determinants of bargaining. This specific impact of social incomes on generated incomes, called here the bargaining effect, accompanies the traditional income effect in unitary household models.

\footnotetext{
${ }^{2}$ Leuthold (1968), Garfinkel et al (1990), Licona (1997)

${ }^{3}$ The incidence of poverty appears to be related to differentials in participation, while the depth of poverty is associated with working hour differentials. According to the CASEN 1996 household income survey (MIDEPLAN, 1996), participation rates are uniform across the working age extreme and moderate poor (45\%) but are higher for the non-poor (54\%). Only the extreme poor appear to work less hours than the moderate and non-poor (42 to 44 weekly hours, respectively). Men participate more and work longer hours than women (a gap of 35\% and 4 weekly hours, respectively). In addition, household heads participate more $(2.5 \%)$ but work similar hours (44 a week) compared to household non-heads. Other differences in work effort found by age and skill of individuals as well as number of children and location of the household indicate that individuals may adjust their labor supply differently through participation and working hours.
} 
Collective labor supply modeling requires the inclusion of individual allocation weights, which shape the bargaining or sharing rule. Following the distinction in the literature, exogenous and endogenous determinants of bargaining are differentiated here. The effect that the variation of exogenous determinants has on the bargaining function is a priori open and can either strengthen or weaken the bargaining position of each individual. However, increases in the non-labor incomes controlled by an individual are expected to strengthen his or her bargaining position, while they weaken the position of remaining members. All individual weights in the sharing rule must add up to unity, and individual weights may range from zero (i.e., no control of his or her own resources) to unity (if the individual controls all the resources in the household). The resulting maximization problem under intrahousehold bargaining is then equivalent to a one-stage representation in which individuals maximize their own utility functions after some share of household income has been apportioned to them in accordance with their bargaining strength (Chiappori, 1997). The first order condition leads to the optimal participation condition. Similarly, labor reaction curves for each household member (grouped as household head and household non-head members) are derived (see Appendix 1). Both optimal conditions differ from the unitary model in that they introduce individual allocation weights from the bargaining rule and a separate treatment of cash and in-kind non-labor incomes, depending on their transferability.

The effects of social transfers on working hours under alternative intrahousehold allocation models are predicted by working out their partial derivatives on each work dimension and on each category of household members. The predicted effects reported in Table 1 show that the microeconomic effects of social transfers are not systematically negative. More important, distinctive effects of social transfers help 
differentiate unitary from collective models. As individual cash transfers can be redistributed to other household members, they do not necessarily increase the bargaining power of the original recipient, but rather the power of the individual(s) who gain their ultimate control. In contrast, in-kind transfers cannot be part of intrahousehold redistribution, thus enhancing only the bargaining position of their original recipients. It may still be argued that higher social transfers associated with time spent in school or undergoing medical treatment (that is, not working) do not necessarily improve the bargaining position of their beneficiaries in the short run. ${ }^{4}$ However, the subsidies associated with public education or medical services cannot be re-directed to other household members. As such, beneficiaries appropriate the marginal bargaining power associated with such transfers. Consequently, the impact that in-kind transfers and cash transfers may have on the intrahousehold distribution of power are potentially different. ${ }^{5}$ The aggregate impact of social transfers becomes complex and ambiguous in the presence of bargaining due to counterbalancing impacts among direct, indirect, and bargaining effects.

\section{<TABLE 1>}

\section{Estimating labor supply household models}

A separate modeling of each labor dimension does not prevent sample selection bias, endogeneity, and measurement errors in wages and virtual incomes, ${ }^{6}$ however. These

\footnotetext{
${ }^{4}$ In the long run, expected higher earnings from increased human capital may improve the future bargaining position within the household, or even lead to the creation of a new household.

${ }^{5}$ An alternative interpretation - that time spent in activities other than labor should be divided into those increasing relative bargaining power (such as human capital investment) and those decreasing it (such as leisure) - is not free of problems. For example, nutritional cash transfers should then have the same bargaining effect on labor decisions as, say, in-kind educational transfers. As seen below, however, the effects of cash and in-kind transfers on labor decisions in Chile are not equal.

${ }^{6}$ Virtual income is the hypothetical income that a tax-payer would find untaxed under an alternative system with the same flat tax rate that he or she pays in the current tax system. Virtual incomes are typically subject to sample selection (like wages) because individuals participating in the labor market
} 
biases in the labor and household surveys are typically corrected using the Heckman (1979) estimation technique and instrumental variables. This paper adds to this tradition. Working hour decisions are modeled through a sample selection corrected ordinary least squares (OLS) including the same wages and virtual incomes corrected by the Heckman procedure. The Mills Ratios constructed from the Heckman technique are used in the estimation of the OLS only for individuals reporting positive working hours and positive labor incomes. The same explanatory variables included in the working hour model are used in the participation model, given that both dimensions are part of the same process underlying the decision to supply work effort. Three specifications for both participation and working hour models are used, gradually disaggregating non-labor income categories. The first specification disaggregates all possible categories of social incomes; the second divides transfers into individual and other household members' categories; the last specification brings together all categories of individual and other household members' transfers. A final disaggregation singles out participation and working hours by socio-economic group. According to the position of the household with respect to the extreme and moderate official poverty lines adjusted for scale economies, households are categorized as extreme poor, moderate poor and non-poor. ${ }^{7}$ The most disaggregated specifications for participation ([1]) and working hours ([2]) are, respectively, as follows:

$$
\begin{aligned}
\pi_{i}= & \gamma_{0 i}+\gamma_{1 i} \ln w(1-t)_{i}+\gamma_{2 i}\left[\ln \hat{w(1-t)]^{2}}{ }_{i}+\gamma_{3 i} \ln V I_{i}+\gamma_{4 i} \ln \left(N_{i}\right)+\gamma_{5 i} \ln \left(S_{i}^{c}\right)+\gamma_{6 i} \ln \left(S_{i}^{e}\right)+\right. \\
& \gamma_{7 i} \ln \left(S_{i}^{h}\right)+\gamma_{8 i} \sum_{j} \ln \left(N_{j}\right)+\gamma_{9 i} \sum_{j} \ln \left(S_{j}^{c}\right)+\gamma_{10 i} \sum_{j} \ln \left(S_{j}^{e}\right)+\gamma_{11 i} \sum_{j} \ln \left(S_{j}^{h}\right)+\sum_{m} \gamma_{m i} Z_{m i}+\varepsilon_{m i}
\end{aligned}
$$

may have a stronger taste for work and a higher inclination to "select" higher marginal tax rates and, therefore, a larger virtual income. See Hausman (1985).

${ }^{7}$ Official extreme and moderate poverty lines in 1996 Chile amounted to Ch\$ 13,024 and Ch\$23,108 for rural households, and $\mathrm{Ch} \$ 17,136$ and $\mathrm{Ch} \$ 34,272$ for urban households (MIDEPLAN, 2000). Household sizes were adjusted by the Rothbarth method used in World Bank (1997). 


$$
\begin{aligned}
& \ln H_{i}=\eta_{0 i}+\eta_{1 i} \ln w(1-t)_{i}+\eta_{2 i}[\ln w(1-t)]_{i}^{2}+\eta_{3 i} \ln \hat{V I} I_{i}+\eta_{4 i} \ln \left(N_{i}\right)+\eta_{5 i} \ln \left(S_{i}^{\mathfrak{c}}\right)+ \\
& \eta_{6 i} \ln \left(S_{i}^{e}\right)+\eta_{7 i} \ln \left(S_{i}^{h}\right)+\eta_{8 i} \sum_{j} \ln \left(N_{j}\right)+\eta_{9 i} \sum_{j} \ln \left(S_{j}^{c}\right)+\eta_{10 i} \sum_{j} \ln \left(S_{j}^{e}\right)+\eta_{11 i} \sum_{j} \ln \left(S_{j}^{h}\right)+ \\
& \sum_{\mathrm{m}} \eta_{\mathrm{mi}} z_{\mathrm{mi}}+\eta_{\mathrm{m}+1} \lambda_{\mathrm{i}}+\varepsilon_{\mathrm{Hi}}
\end{aligned}
$$

where $\pi_{\mathrm{i}}$ represents the individual probability of participation in the labor market; $\mathrm{H}_{\mathrm{i}}$, individual working hours (conditional on participation); $\mathrm{w}(1-\mathrm{t})_{\mathrm{i}}$, individual net labor incomes; $\mathrm{VI}_{\mathrm{i}}$, individual virtual incomes; $\mathrm{N}_{\mathrm{i}}$, individual non-labor primary incomes (i.e., financial incomes, rents, pensions and self-consumption); $\mathrm{S}_{\mathrm{i}}^{\mathrm{c}}$, individual cash social transfers; $S_{i, j}^{e, h}$, in-kind social transfers on education (k="e") and health (k=”h"), of individual “i”, or, other household member “j”, respectively; and $\mathrm{Z}_{\mathrm{im}}$, exogenous variables, which include individual, household and regional characteristics affecting individuals' participation. Individual exogenous determinants of labor decisions refer to human capital (i.e., years of school and linear and quadratic forms of age); marital status; gender; and the position of the individual within the household (i.e., head and non-heads). Household characteristics include the demographic composition of the household. A final characteristic is the location of the household. Additional variables are chosen specifically for non-heads in order to control for the characteristics of the household head. Such characteristics include the income of the household head; his or her labor status (and if working, whether formal or informal); his or her occupation; and the gender of the household head. These variables provide an insight into whether the gender and other conditions of the household head have different effects on non-heads. In Chile, Rubalcava and Contreras (1999) found that this was the case, based on information on the nutritional status of children. 


\section{Testing Alternative Intrahousehold Models}

The testing strategy consists of comparing the signs of theoretically predicted effects of social transfers on work decisions with their observed effects estimated as elasticities from labor supply models. ${ }^{8}$ As argued above, social transfers under unitary and collective models have different predicted effects on the decision to participate, depending on their cash or in-kind nature and who controls them. As the predicted effects on working hours are not distinctive across intrahousehold allocation models, they are unsuitable for testing bargaining specifications. Table 2 details the proposed tests.

\section{$<$ TABLE 2>}

\section{SOCIAL TRANSFERS IN CHILE}

Social transfers in mid-1990s Chile were affected by the reforms of the Pinochet administration in the 1970s and 1980s and the new social agenda, 'growth with equity', of the Concertación administrations through the 1990s. Social policies in the 1990s adopted a more comprehensive strategy, replacing the low-priority anti-cyclical and ultra-targeted expenditures of the 1980s. Although the earlier competition and decentralization reforms were not reversed, the emphasis of social policy-making shifted towards increases in the quality of provision and a more encompassing targeting. This strategy was also used as a redistributive tool as high-income groups

\footnotetext{
${ }^{8}$ The underlying assumption is that there should not be a substantial gap between optimal (desired) and observed (actual) work effort. By and large, this assumption holds for the tight Chilean labor market in the mid-1990s, where work supply was typically absorbed by an increasing demand throughout a period of rapid and sustained economic growth. Job creation in Chile grew at a faster pace than did the labor force and the population. Low unemployment rates in the first half of the 1990s suggest that labor was certainly not constrained by the supply of work.
} 
increasingly opted out of public provision systems, leaving public schools and clinics for low-income groups. Ultimately, the new agenda aimed at distributing the proceeds of the resumed sustainable high economic growth among all Chileans, without jeopardizing macroeconomic balances. Substantial increases of per capita social expenditures $^{9}$ were therefore not financed by increases in debt but by an unprecedented tax reform resulting from the political consensus of all parties in Congress.

At a disaggregated level, analysis of the distributive impact of these social policy changes requires that monthly unitary social transfers are first valued and then imputed to their beneficiaries. To impute such benefits, available aggregated data on costs and beneficiaries of public social services, on the one hand, and information on self-reported beneficiaries from the 1996 CASEN household survey (MIDEPLAN, 1996), on the other, are linked. Appendix 2 presents descriptive socioeconomic statistics on households as well as on the nature of transfers, their providers, beneficiaries and benefits for that year. The current valuation of benefits follows traditional practice by equating them to provision costs (Selowsky, 1979) under the principle of effective transfers. Contrary to a previous valuation in Chile (see Millán et al, 1999), only benefits effectively disbursed are imputed even when they differ from official statutory values. Specific to the Chilean context, the imputation of medical transfers distinguishes between billed and unbilled benefits. This distinction separates two components of medical subsidies: deductions in the medical bill to the patient (according to his/her socio-economic status) and the gap between real effective costs and billed costs, respectively. Finally, estimated benefits are imputed to selfreported beneficiaries on an individual basis.

\footnotetext{
${ }^{9}$ The increases totaled some $50 \%$ in real terms from US\$ 230 to US\$347 (in 1986 prices) between 1990 and 1996.
} 


\section{RESULTS}

\section{Estimating Social Transfers Effects}

Estimates clearly show that social transfers have on aggregate a significant but rather small effect on working decisions. This is shown in the upper section of Table 3. At the most aggregated level, a 100\% increase in total non-labor incomes would have decreased participation by only $0 \%$ to $5 \%$, and even less for working hours (between $0 \%$ and $1 \%$ ). These estimates fall within ranges reported in previous studies, although this is not especially revealing: a prudent interval for estimates reported in studies in the US and UK averages the elasticities of non-labor incomes at between $0 \%$ and $20 \%$ for male working hours and between $-20 \%$ and $0 \%$ for female working hours (see Killingsworth and Heckman, 1986). Although those studies and the present one are not strictly comparable because of differences in the categories of incomes and sample groups, estimated elasticities are reassuringly close.

As expected, participation elasticities are larger than working hour elasticities. ${ }^{11}$ Elasticities for female non-heads are lower than those for female heads. The opposite is true for men, probably indicating the responsibility of the traditional breadwinner to cater for the rest of the household. Also, this work effort may well limit their possibilities of raising additional effort to any degree. In turn, lower elasticities of female non-heads may indicate a restricted access to labor markets, which can be attributed to greater household responsibilities than those of male household members. These responsibilities include child care and maintenance

\footnotetext{
${ }^{11}$ Participation elasticities are expected to be larger than working hour elasticities because the direct, indirect, and bargaining effects of the former typically work in the same direction. This is not the case for working hours. See Table 1 above.
} 
activities, as documented by Juster and Stafford (1991) and Floro (1995) for developing countries, and Rubalcava and Contreras (1999) specifically for Chile.

Estimates for disaggregated specifications of social incomes suggest that household members have different access to household incomes. In contrast with the prediction of the unitary model, elasticities of individual incomes and those of other household members clearly differ (see the intermediate section in Table 3). This holds true for men and women, heads and non-heads, and participation and working hours. Related to other household members' elasticities, both female and male elasticities have either neutral or positive effects on the individual decision to work. The size of these effects is small: an increase of between $0 \%$ and $19 \%$ in participation following increases of $100 \%$ in these incomes, and $-0.4 \%$ and $6 \%$ for working hours. When some individuals within the household increase their incomes, other household members seem to react as if trying to maintain their income balance inside the household. Once again, this is at odds with the unitary model and more indicative of some bargaining process within the household.

At the most disaggregated level of social incomes (see the lower section in Table 3), in-kind transfers have generally larger effects on both participation and working hour decisions than cash transfers do. This is likely to be the result of larger incomes delivered through in-kind transfers and the inability of individuals to control other individuals' in-kind transfers. Interestingly, individual cash and in-kind transfers received by female members have a negative effect both on their participation and working hours. By contrast, the effects of other household members' transfers on their working decision are either neutral or positive. Social incomes received by men have either negative or neutral effects both on participation and working hours. This is true for both head and non-head males. Negative effects on participation suggest once 
again that males are most likely to use such incomes to consume more leisure rather than to strengthen their bargaining position. Other household members' social transfers do not seem to have significant (or if statistically significant, not substantial) effects on the decision to work, either among heads or non-heads.

\section{<TABLE 3>}

\section{Tests on Intrahousehold Allocation}

Tests strongly reject the unitary model in all cases. Interestingly, tests on collective models of intrahousehold allocation (see Table 4) suggest the presence of collective behavior among Chilean households only for certain categories of members. Thus, the hypothesis of endogenous bargaining determined by social transfers holds for all groups except male household heads. Even so, neither exogenous nor endogenous bargaining seems to explain individual behavior among poor households (see Table 5). Furthermore, the endogenous bargaining hypothesis is only proven among nonpoor households, which receive a lower share of social transfer vis-à-vis labor incomes. There may be several reasons for this. Categories other than income (such as asset ownership, as suggested by Licona, 1997) may well explain differences in behavior. Also, categories of social cash transfers may have worked in different directions. Thus, assistance cash transfers and work-related family allowances may have different impacts on the redistribution strategy of the household, given that their receipt depends on different circumstances. ${ }^{12}$ Another possible explanation is that poor households do not use social transfers strategically to gain or enforce bargaining power within their households: rather, they may use such transfers as an investment

\footnotetext{
${ }^{12}$ Unfortunately, the 1996 CASEN household survey does not provide sufficient information on assets or on disaggregated categories of cash transfers to allow for exploring the relevance of these conjectures.
} 
for the future. Poor households have fewer investment opportunities and less access to private services with which to build their human capital stocks than non-poor households. It is also likely — without contradicting previous explanations — that other sources of incomes are more important for bargaining purposes. In particular, one may expect labor incomes to be the main determinant of bargaining. The larger size of estimated wage elasticities, compared to social transfer elasticities, suggests that this may well be the case.

\section{<TABLES 4 AND 5>}

\section{CONCLUSIONS}

The empirical estimates of this paper confirm that social transfers in Chile can be used for redistributive purposes without eroding either macroeconomic balances or the income-generation ability of those whom they are meant to help the most. Had social transfers doubled in 1996, average labor supply would only have decreased by between 1 and 27 minutes per week! Unfortunately, there is no evidence that shifting the composition of social benefits towards in-kind transfers would automatically enhance the bargaining position of the most vulnerable members within households. Instead, evidence appears conclusive in rejecting both unitary household models and exogenously determined bargaining. In spite of an asymmetric distribution of responsibilities within the household, the hypothesis of endogenous bargaining is only accepted among the non-poor. Among poor households, social transfers are unlikely to be used in strategic power relations in the short run, but rather as investments for the long run. At the same time, more substantial sources of incomes, such as labor, may also determine endogenous bargaining. 


\section{APPENDIX 1: HOUSEHOLD MAXIMIZATION PROBLEM WITH INTRAHOUSEHOLD BARGAINING}

After the classical maximization problem is expanded to include the sharing rule, the intrahousehold bargaining problem becomes:

$$
\begin{array}{ll}
\max _{C_{i}, L_{i}} U=\left(C_{i}-\chi_{i}\right)^{\alpha}\left(L_{i}-\lambda_{i}\right)^{\beta_{i}} \quad, \alpha_{i}+\beta_{i} \geq 1 \\
\text { s.t. } \quad \mathrm{X}=\mathrm{Lw}+\mathrm{C} \\
\mathrm{X}=\mathrm{Tw}+\mathrm{N}+\mathrm{S}^{\mathrm{c}}+\mathrm{S}^{\mathrm{k}} \\
\mathrm{X}_{\mathrm{i}}=\theta_{\mathrm{i}} \mathrm{X} \\
\mathrm{L}_{\mathrm{i}} \leq \mathrm{T} \\
\mathrm{L}_{\mathrm{i}}+\mathrm{H}_{\mathrm{i}}=\mathrm{T} \\
\mathrm{C}_{\mathrm{i}}, \mathrm{L}_{\mathrm{i}}>0 \\
\left(C_{i}-\chi_{i}\right) \geq 0 \\
\left(L_{i}-\lambda_{i}\right) \geq 0 \\
\sum_{i} L_{i}=L \\
\sum_{i} C_{i}=C \\
\sum_{i} w_{i} w_{i}=w \\
\sum_{i} X_{i}=X \\
\sum_{\mathrm{i}} \mathrm{N}_{\mathrm{i}}^{\mathrm{s}}=\mathrm{N} \\
\end{array}
$$


where $\mathrm{C}$ represents individual consumption; $L$, the leisure composite; $H$, work effort (measured in working hours); $\chi$, the minimum level of consumption (whose equivalent income value can be thought as the extreme poverty line); $\lambda$, the minimum level of leisure; $w$, wage or unitary labor income; $X$, full income; $T$, the maximum time available; $N$, the non-labor primary income; $S^{c}$, cash social transfers; and $S^{k}$, inkind social transfers on education, health, housing subsidies.

A convenient way to represent the set of partial derivatives for endogenous determinants of bargaining without loss of generality is the following:

$$
\begin{aligned}
& \theta_{i}=a \frac{N_{i}+S_{i}^{c}+S_{i}^{k}}{N_{j}+S_{j}^{c}+S_{j}^{k}}, \quad a>0 \\
& \theta_{j}=b \frac{N_{j}+S_{j}^{c}+S_{j}^{k}}{N_{i}+S_{i}^{c}+S_{i}^{k}}, \quad b>0
\end{aligned}
$$

The first order condition of the maximization problem leads to the optimal participation condition:

$$
\begin{aligned}
& \pi_{\mathrm{i}}=1 \text { if } \mathrm{w}_{\mathrm{i}}-\frac{\beta_{\mathrm{i}}}{\alpha_{\mathrm{i}}} \frac{\theta_{\mathrm{i}} \cdot\left(\mathrm{N}_{\mathrm{i}}+\mathrm{S}_{\mathrm{i}}^{\mathrm{c}}+\mathrm{N}_{\mathrm{j}}+\mathrm{S}_{\mathrm{j}}^{\mathrm{c}}\right)+\mathrm{S}_{\mathrm{i}}^{\mathrm{k}}-\chi_{\mathrm{i}}}{\mathrm{T}-\lambda_{\mathrm{i}}}>0 \\
& \pi_{\mathrm{i}}=0 \text { otherwise }
\end{aligned}
$$

Similarly, optimal working hours can be derived from solving the following reaction-curve equations:

$$
\begin{aligned}
& H_{i}=\frac{1}{\alpha_{i}+\theta_{i} \beta_{i}}\left[\alpha_{i}\left(T-\lambda_{i}\right)-\frac{\beta_{i}}{w_{i}}\left[\theta_{i} H_{j} w_{j}+\theta_{i}\left(N_{i}+N_{j}+S_{i}^{c}+S_{j}^{c}\right)+S_{i}^{k}-\chi_{i}\right]\right. \\
& H_{j}=\frac{1}{\alpha_{j}+\theta_{j} \beta_{j}}\left[\alpha_{i}\left(T-\lambda_{j}\right)-\frac{\beta_{j}}{w_{j}}\left[\theta_{j} H_{i} w_{i}+\theta_{j}\left(N_{i}+N_{j}+S_{i}^{c}+S_{j}^{c}\right)+S_{j}^{k}-\chi_{j}\right]\right.
\end{aligned}
$$




\section{APPENDIX 2: DESCRIPTIVE SOCIOECONOMIC STATISTICS OF \\ HOUSEHOLDS AND SOCIAL TRANSFERS IN CHILE, 1996.}

\section{Household Descriptive Statistics}

\begin{tabular}{|c|c|c|c|c|}
\hline & \multicolumn{2}{|c|}{ Female } & \multicolumn{2}{|c|}{ Male } \\
\hline & Head & Non-head & Head & Non-head \\
\hline \multicolumn{5}{|l|}{ Individual characteristics } \\
\hline Percentage $(\%)$ & 10.8 & 89.2 & 39.8 & 60.2 \\
\hline Schooling years & 8.3 & 7.6 & 9.8 & 6.4 \\
\hline Age & 54.5 & 26.9 & 45.1 & 17 \\
\hline Marriage Rate $(\%)$ & 13.5 & 42.6 & 90.7 & 8.5 \\
\hline Location in urban areas (\%) & 89.3 & 84.5 & 83.4 & 82.8 \\
\hline Location in Santiago $(\%)$ & 44.1 & 40.9 & 39.3 & 39.1 \\
\hline \multicolumn{5}{|l|}{ Household characteristics } \\
\hline Size & \multicolumn{2}{|c|}{3.9} & \multicolumn{2}{|c|}{4.2} \\
\hline Number of children aged $0-14$ & \multicolumn{2}{|c|}{0.8} & \multicolumn{2}{|c|}{1.3} \\
\hline Number of children aged $0-11$ & \multicolumn{2}{|c|}{0.6} & \multicolumn{2}{|c|}{1.0} \\
\hline Number of elder (aged $65+$ ) & \multicolumn{2}{|c|}{0.4} & \multicolumn{2}{|c|}{0.1} \\
\hline Number of female elder (aged $65+$ ) & \multicolumn{2}{|c|}{0.3} & \multicolumn{2}{|c|}{0.1} \\
\hline Number of servants & \multicolumn{2}{|c|}{0.1} & \multicolumn{2}{|c|}{0.1} \\
\hline Number of non-participant females & \multicolumn{2}{|c|}{0.9} & \multicolumn{2}{|c|}{0.4} \\
\hline \multicolumn{5}{|l|}{ Labor characteristics } \\
\hline Participation (\%) & 45.8 & 33.3 & 82.0 & 43.2 \\
\hline Weekly working hours & 41.7 & 41.8 & 46.6 & 44.2 \\
\hline \multicolumn{5}{|l|}{ Incomes (1986 US\$) } \\
\hline \multicolumn{5}{|l|}{ Individual incomes } \\
\hline $\begin{array}{l}\text { From principal occupation, net of } \\
\text { taxes }\end{array}$ & 106.5 & 59.0 & 285.8 & 80.8 \\
\hline Primary incomes other than labor * & 18.6 & 18.0 & 22.5 & 14.5 \\
\hline Cash transfers & 1.5 & 1.1 & 1.2 & 1.2 \\
\hline Education in-kind transfers & 0.02 & 5.1 & 0.01 & 8.2 \\
\hline Health in-kind transfers & 2.2 & 1.6 & 0.9 & 1.2 \\
\hline \multicolumn{5}{|l|}{$\begin{array}{l}\text { Other household members' } \\
\text { incomes }\end{array}$} \\
\hline $\begin{array}{l}\text { From principal occupation, net of } \\
\text { taxes }\end{array}$ & 208.6 & 444.1 & 171.6 & 430.6 \\
\hline Primary incomes other than labor * & 3.0 & 4.6 & 3.7 & 5.1 \\
\hline Cash transfers & 14.3 & 21.1 & 20.3 & 20.6 \\
\hline Education in-kind transfers & 3.1 & 5.1 & 4.5 & 5.6 \\
\hline \multicolumn{5}{|l|}{ Health in-kind transfers } \\
\hline All household incomes & & & & \\
\hline All primary & \multicolumn{2}{|c|}{474.3} & \multicolumn{2}{|c|}{502.6} \\
\hline All monetary & \multicolumn{2}{|c|}{499.9} & \multicolumn{2}{|c|}{527.7} \\
\hline All monetary and in-kind & \multicolumn{2}{|c|}{526.1} & & \\
\hline
\end{tabular}

Source: Author's estimates from 1996 CASEN household survey (MIDEPLAN, 1996).

Note: * Incomes expressed in monthly 1986 US\$. Primary incomes other than labor refer to pensions, financial incomes, rents and self-consumption. 


\section{Description and Valuation of Social Transfers in Chile}

\begin{tabular}{|c|c|c|c|c|}
\hline TYPE OF TRANSFERS & PROVIDER & BENEFITS & BENEFICIARIES & $\begin{array}{l}\text { VALUE } \\
\text { monthly } \\
1986 \text { US\$ }\end{array}$ \\
\hline \multicolumn{5}{|l|}{ In-kind education transfers } \\
\hline \multicolumn{5}{|l|}{ MINEDUC General Subsidy } \\
\hline Municipal & MINEDUC & Total subsidies reported by & Students registered in and & \\
\hline Pre-basic & & MINEDUC for each level and & attending municipal pre-basic, & 14.1 \\
\hline Basic & & category of public education & basic and secondary schools & 15.3 \\
\hline Secondary, humanities & & & & 18 \\
\hline Secondary, technology & & & & 20 \\
\hline Special & & & & 50.1 \\
\hline Adults & & & & 12.5 \\
\hline Publicly subsidized private & MINEDUC & Total subsidies reported by & Students registered in and & \\
\hline Pre-basic & & MINEDUC for each level and & attending publicly subsidized & 13.6 \\
\hline Basic & & category of publicly subsidized & private pre-basic, basic and & 14.1 \\
\hline Secondary, humanities & & private schools & secondary schools & 17.1 \\
\hline Secondary, technology & & & & 18.5 \\
\hline Special & & & & 37.5 \\
\hline Adults & & & & 11.8 \\
\hline Pre-basic subsidy & JUNJI & $\begin{array}{l}\text { Costs involved in provision: personnel } \\
\text { costs, goods and services, food and } \\
\text { material provided at centers, and } \\
\text { investment in equipment }\end{array}$ & $\begin{array}{l}\text { Students registered in JUNJI } \\
\text { centers. }\end{array}$ & 42.5 \\
\hline Special integration subsidy & INTEGRA & $\begin{array}{l}\text { Personnel costs, goods and services, } \\
\text { food in centers, investment in } \\
\text { equipment }\end{array}$ & $\begin{array}{l}\text { Students aged } 0-6 \text { registered in } \\
\text { INTEGRA centers. }\end{array}$ & 40.5 \\
\hline Books at school program & MINEDUC & MINEDUC reported total costs & $\begin{array}{l}\text { Students registered in pre-basic } \\
\text { and basic schools }\end{array}$ & 0.1 \\
\hline School food program & JUNAEB & Simple average unitary price paid by & Students registered in basic and & \\
\hline Breakfast / tea & & JUNAEB on effectively disbursed & secondary public and & 4.1 \\
\hline Lunch & & rations, by categories of food rations & subsidized schools targeted as & 7.7 \\
\hline Breakfast + lunch / lunch + tea & & & vulnerable by JUNAEB & 10.5 \\
\hline Breakfast + lunch + tea & & & & 14.6 \\
\hline Health program & JUNAEB & $\begin{array}{l}\text { Total costs of provision of medical } \\
\text { treatments that follow up initial } \\
\text { teacher's checkups. }\end{array}$ & $\begin{array}{l}\text { Students registered in first to } \\
\text { sixth grade basic schools, both } \\
\text { municipal and/or publicly } \\
\text { subsidized }\end{array}$ & 1.2 \\
\hline Oral hygiene program & JUNAEB & Total costs of provision as reported & $\begin{array}{l}\text { Students registered in first to } \\
\text { sixth grade basic schools, both } \\
\text { municipal and/or publicly } \\
\text { subsidized }\end{array}$ & 0.7 \\
\hline School material program & JUNAEB & Total costs per set of school material & $\begin{array}{l}\text { Beneficiaries of School food } \\
\text { program }\end{array}$ & 0.1 \\
\hline
\end{tabular}

\section{In-kind health transfers \\ Transfers from National Health}

Network

Institutional modality

Consults

Laboratory exams

X-ray exams

Surgery

Dental care

Non-Caesarean delivery

Caesarean delivery

Hospitalization

Effective modality

Consults

Laboratory exams

$\mathrm{X}$-ray exams

Surgery

Dental care

Non-Caesarean delivery

Caesarean delivery

Hospitalization

Supplementary feeding program

Basic feeding

Women

0-11 month-old

12-23 month-old

2-5 year-old
National Health Network

National Health Network

Health Ministry
Total billed and unbilled costs for provision of medical services reported by $\mathrm{NHN}$ budgets for each category of co-financing
Institutional modality public users

Total billed costs reported by NHN

across medical categories (no cofinancing categories)

Unitary costs of complementary food sets comprising milk, cereal and rice

Pregnant women, mothers at nutritional risk and infants aged 0-5 


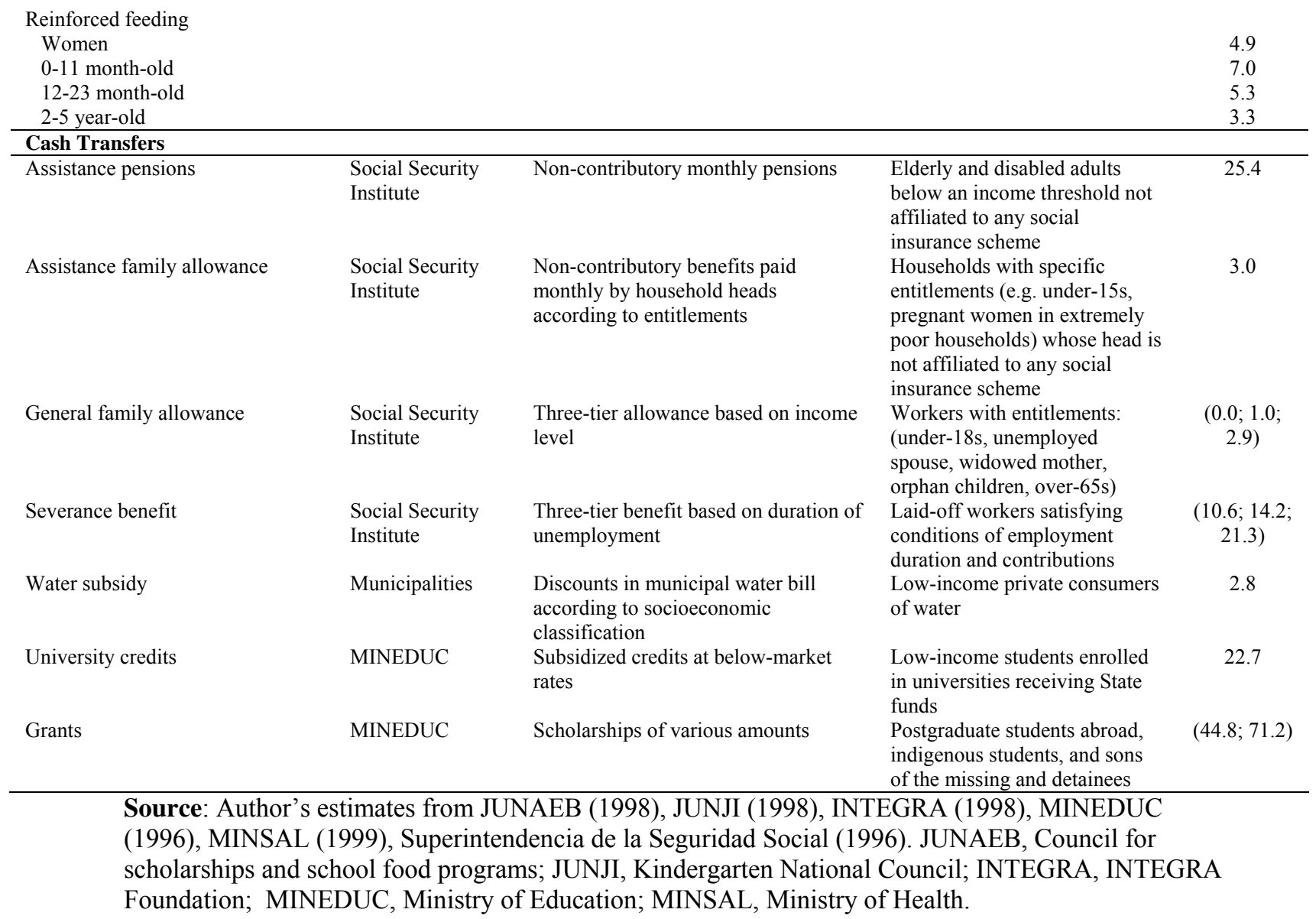


APPENDIX 3: PARTICIPATION AND WORKING HOUR ESTIMATES

\section{ALL HOUSEHOLDS}

\begin{tabular}{|c|c|c|c|c|c|c|c|c|}
\hline & \multicolumn{4}{|c|}{ Female } & \multicolumn{4}{|c|}{ Male } \\
\hline & \multicolumn{2}{|c|}{ Participation } & \multicolumn{2}{|c|}{ Working Hours ${ }^{(\mathbf{1})}$} & \multicolumn{2}{|c|}{ Participation } & \multicolumn{2}{|c|}{ Working Hours ${ }^{(\mathbf{1})}$} \\
\hline & Head & Non-Head & Head & Non-head & Head & Non-head & Head & Non-head \\
\hline \multicolumn{9}{|l|}{ Individual characteristics: } \\
\hline Age & $* * 0.047$ & $* * 0.022$ & -0.006 & 0.006 & $* *-0.005$ & $* * 0.002$ & -0.001 & $* *_{-} 0.039$ \\
\hline Age squared ${ }^{(2)}$ & $* *-0.001$ & $* *-0.0004$ & & & & & 0.00001 & $* * 0.0004$ \\
\hline Marriage dummy & $* *-0.232$ & $* *-0.040$ & -0.049 & 0.002 & $* * 0.009$ & 0.025 & 0.004 & 0.017 \\
\hline \multicolumn{9}{|l|}{ Household characteristics: } \\
\hline Number of children, 0-11 & $* *_{-} 0.101$ & $* *-0.051$ & -0.017 & 0.007 & 0.002 & $* * 0.028$ & 0.004 & -0.007 \\
\hline Number of children, 12-14 & $* *_{-} 0.093$ & $* *_{-} 0.058$ & 0.021 & 0.016 & $* * 0.010$ & $* *-0.074$ & 0.0004 & $* * 0.031$ \\
\hline $\begin{array}{l}\text { Number of single women out of } \\
\text { the labor market }\end{array}$ & $* *-0.512$ & $* *-0.123$ & $* * 0.094$ & $* * 0.046$ & $* 0.006$ & -0.008 & 0.007 & $* * 0.025$ \\
\hline Number of elderly women & $* * 0.211$ & $* * 0.066$ & -0.046 & $* *-0.049$ & $* *-0.025$ & -0.030 & -0.006 & -0.008 \\
\hline Number of servants & $* * 0.294$ & $* * 0253$ & -0.071 & 0.008 & -0.005 & $* * 0.052$ & 0.0001 & 0.006 \\
\hline \multicolumn{9}{|l|}{ Individual labor income variables: } \\
\hline Estimated wage, log & $* * 0.219$ & $* * 0.216$ & 0.601 & $* * 0.589$ & $* * 0.020$ & $* * 0.525$ & $* * 0.863$ & $* * 1.027$ \\
\hline Estimate wage squared, $\log ^{(2)}$ & & & -0.052 & $* *-0.052$ & & & $* *-0.064$ & $* *-0.074$ \\
\hline Estimated virtual income, log & 0.153 & -0.153 & -0.331 & 0.472 & $* *-0.115$ & $* *-3.499$ & -0.015 & -0.477 \\
\hline \multicolumn{9}{|l|}{ Individual non-labor incomes: } \\
\hline Primary & $* * 0.044$ & $* * 0.034$ & 0.003 & 0.002 & $* *-0.003$ & $* * 0.005$ & $* * 0.003$ & $* * 0.007$ \\
\hline Cash transfers & $* *_{-} 0.011$ & $* * 0.035$ & $*-0.010$ & $* *_{-} 0.007$ & -0.001 & $* *_{-} 0.004$ & $* *-0.023$ & $* * 0.005$ \\
\hline In-kind education & $* *-0.016$ & $* *-0.009$ & $* *-0.015$ & $*-0.007$ & $* *-0.004$ & $* *-0.021$ & -0.001 & 0.004 \\
\hline In-kind health & $* *-0.059$ & $* *-0.036$ & $* *-0.066$ & $*_{-}-0.061$ & $* *_{-} 0.017$ & $* *-0.079$ & 0.005 & $* *-0.046$ \\
\hline \multicolumn{9}{|l|}{$\begin{array}{l}\text { Non-labor incomes from other } \\
\text { members: }\end{array}$} \\
\hline Primary & -0.005 & $* * 0.038$ & -0.010 & $* * 0.043$ & $* * 0.001$ & $* * 0.037$ & 0.0004 & $* * 0.047$ \\
\hline Cash transfers & $* *_{-} 0.011$ & -0.001 & -0.008 & $*_{-} 0.004$ & $* *-0.003$ & $* *-0.005$ & $* *-0.002$ & 0.001 \\
\hline In-kind education & $* * 0.021$ & -0.007 & 0.003 & $*_{-0.004}$ & 0.0002 & $* * 0.006$ & -0.0002 & -0.002 \\
\hline In-kind health & $* * 0.023$ & $* * 0.005$ & 0.002 & $* *-0.006$ & 0.001 & $* 0.002$ & $* 0.001$ & -0.0004 \\
\hline \multicolumn{9}{|l|}{ Household head characteristics: } \\
\hline Kinship & & 0.001 & & $* *-0.012$ & & $* *-0.023$ & & $* *-0.008$ \\
\hline Male dummy & & $* *-0.151$ & & 0.001 & & $* *-0.078$ & & $* * 0.033$ \\
\hline Estimated wage, log & & $* * 0.016$ & & $* * 0.046$ & & $* * 0.111$ & & $* * 0.100$ \\
\hline Estimated wage squared, $\log ^{(2)}$ & & $* *-0.004$ & & $* *-0.009$ & & $* *-0.018$ & & $* *_{-} 0.016$ \\
\hline \multicolumn{9}{|l|}{ Labor status: } \\
\hline Unemployed & & $* * 0.147$ & & -0.124 & & 0.062 & & 0.010 \\
\hline Informal & & $* *-0.176$ & & 0.099 & & -0.057 & & 0.032 \\
\hline Formal & & $* *-0.183$ & & $* 0.111$ & & -0.106 & & 0.061 \\
\hline \multicolumn{9}{|l|}{ Occupation: } \\
\hline Employer & & $* * 0.322$ & & 0.045 & & $* * 0.159$ & & $* * 0.156$ \\
\hline Self-employed & & $* * 0.282$ & & 0.008 & & $* * 0.128$ & & 0.062 \\
\hline Worker & & $* * 0.238$ & & -0.041 & & 0.056 & & -0.005 \\
\hline \multicolumn{9}{|l|}{ Sector: } \\
\hline Agriculture & & $* *-0.031$ & & -0.004 & & $* * 0.182$ & & -0.014 \\
\hline Manufacture & & $* *-0.040$ & & 0.002 & & 0.032 & & -0.021 \\
\hline Services & & 0.005 & & -0.031 & & $* *-0.081$ & & 0.015 \\
\hline Mills Ratio & & & -0.081 & $* *-0.008$ & & & -0.112 & $* *-0.477$ \\
\hline Constant & -3.516 & 0.001 & 6.464 & -4.541 & $* * 1.698$ & $* * 41.020$ & 1.188 & 6.675 \\
\hline No. Observations & 6,370 & 39,919 & 2,573 & 10,884 & 23,461 & 20,797 & 19,546 & 9,485 \\
\hline Log Likelihood & $-2,129$ & $-10,512$ & & & $-4,678$ & $-7,828$ & & \\
\hline Observed participation & 0.465 & 0.335 & & & 0.891 & 0.501 & & \\
\hline Predicted participation & 0.401 & 0.247 & & & 0.960 & 0.431 & & \\
\hline $\mathrm{F}(\mathrm{n}, \mathrm{d})$ & & & $* * 3.0$ & $* * 5.5$ & & & $* * 7.7$ & $* * 6.1$ \\
\hline $\mathrm{R}^{2}$ & & & 0.0457 & 0.0480 & & & 0.0126 & 0.0939 \\
\hline
\end{tabular}

Source: Author's estimates from 1996 CASEN household survey (MIDEPLAN, 1996).

Note: (1) Working hour models for the extreme and moderate poor are jointly estimated, as the separated sample for extreme poor was not sufficiently large for consistent estimation.

(2) Only the preferred version between the linear and non-linear specification form is reported.

Non-labor primary incomes refer to pensions, rents and financial incomes. All elasticities estimated at the mean of all variables in the model. $(*)$ indicates statistical significance at $10 \%$ level; $(* *)$ statistical significance at $5 \%$ level. 
EXTREMELY POOR

\begin{tabular}{|c|c|c|c|c|c|c|c|c|}
\hline & \multicolumn{4}{|c|}{ Female } & \multicolumn{4}{|c|}{ Male } \\
\hline & \multicolumn{2}{|c|}{ Participation } & \multicolumn{2}{|c|}{ Working Hours ${ }^{(\mathbf{1})}$} & \multicolumn{2}{|c|}{ Participation } & \multicolumn{2}{|c|}{ Working Hours ${ }^{(\mathbf{1})}$} \\
\hline & Head & Non-Head & Head & Non-head & Head & Non-head & Head & Non-head \\
\hline \multicolumn{9}{|l|}{ Individual characteristics: } \\
\hline Age & 0.008 & $* * 0.022$ & $* * 0.024$ & 0.003 & $* * 0.028$ & $* * 0.056$ & $* *-0.006$ & -0.009 \\
\hline Age squared ${ }^{(2)}$ & & -0.0001 & & 0.0001 & $* *-0.0003$ & $* *-0.001$ & & \\
\hline Marriage dummy & -0.255 & -0.057 & 0.087 & -0.142 & 0.114 & -0.036 & $* * 0.132$ & -0.007 \\
\hline \multicolumn{9}{|l|}{ Household characteristics: } \\
\hline Number of children, 0-11 & -0.091 & -0.023 & -0.028 & 0.017 & -0.003 & -0.070 & 0.021 & -0.012 \\
\hline Number of children, $12-14$ & 0.182 & -0.017 & -0.038 & 0.002 & 0.139 & 0.075 & 0.014 & -0.090 \\
\hline $\begin{array}{l}\text { Number of single women out of } \\
\text { the labor market }\end{array}$ & $* *-0.352$ & -0.026 & $* * 0.193$ & 0.078 & $*_{-} 0.070$ & 0.004 & $* * 0.056$ & -0.006 \\
\hline Number of elderly women & 0.071 & $* * 0.143$ & -0.027 & -0.101 & *0.348 & 0.004 & 0.135 & 0.023 \\
\hline Number of servants & $* * 0.524$ & $* * 0.324$ & -0.032 & 0.077 & $* 0.131$ & 0.124 & -0.008 & 0.037 \\
\hline \multicolumn{9}{|l|}{ Individual labor income variables: } \\
\hline Estimated wage, log & 0.003 & $* * 1.241$ & 0.026 & 0.233 & -0.032 & $* * 3.546$ & 1.085 & 0.096 \\
\hline Estimate wage squared, $\log { }^{(2)}$ & & $* *-0.101$ & & -0.021 & & $* *-0.277$ & -0.083 & \\
\hline Estimated virtual income, log & 1.179 & $* * 1.599$ & $* 2.140$ & 0.696 & -1.308 & -1.282 & 0.721 & -0.067 \\
\hline \multicolumn{9}{|l|}{ Individual non-labor incomes: } \\
\hline Primary & $* *-0.049$ & $*_{-} 0.010$ & -0.002 & $* *-0.134$ & $* *-0.031$ & $* *-0.166$ & $* * 0.058$ & -0.008 \\
\hline Cash transfers & 0.013 & $* *-0.014$ & $* *-0.536$ & $* * 0.012$ & -0.005 & * -0.019 & 0.003 & -0.002 \\
\hline In-kind education & -0.011 & $* * 0.146$ & $*_{-} 0.023$ & $* *-0.053$ & $* *-0.036$ & $* * 0.427$ & 0.004 & -0.008 \\
\hline In-kind health & M.C. & $* *-0.042$ & M.C. & $*-0.058$ & M.C. & $* *-0.062$ & $* * 0.049$ & -0.011 \\
\hline \multicolumn{9}{|l|}{$\begin{array}{l}\text { Non-labor incomes from other } \\
\text { members: }\end{array}$} \\
\hline Primary & -0.009 & 0.003 & $* *-0.039$ & -0.021 & 0.009 & $*-0.015$ & 0.018 & -0.004 \\
\hline Cash transfers & 0.002 & -0.003 & -0.006 & -0.004 & -0.008 & $*_{-} 0.015$ & -0.006 & 0.000 \\
\hline In-kind education & 0.020 & $* * 0.011$ & -0.001 & -0.007 & -0.002 & 0.014 & -0.003 & 0.004 \\
\hline In-kind health & 0.015 & -0.002 & 0.014 & -0.008 & 0.001 & -0.005 & -0.005 & 0.013 \\
\hline \multicolumn{9}{|l|}{ Household head characteristics: } \\
\hline Kinship & & 0.004 & & 0.005 & & -0.018 & & -0.020 \\
\hline Male dummy & & $* *-0.145$ & & 0.099 & & $* *-0.318$ & & 0.084 \\
\hline Estimated wage, log & & 0.031 & & $*-0.198$ & & -0.041 & & 0.110 \\
\hline Estimated wage squared, $\log ^{(2)}$ & & -0.010 & & 0.016 & & 0.006 & & $* *-0.029$ \\
\hline \multicolumn{9}{|l|}{ Labor status: } \\
\hline Unemployed & & 0.019 & & -0.235 & & -0.005 & & 0.093 \\
\hline Informal & & -0.216 & & $* * 0.599$ & & -0.152 & & $* * 0.638$ \\
\hline Formal & & $*_{-0.219}$ & & $* * 0.707$ & & -0.260 & & $* 0.521$ \\
\hline \multicolumn{9}{|l|}{ Occupation: } \\
\hline Employer & & M.C. & & -0.157 & & M.C. & & -0.170 \\
\hline Self-employed & & $* * 0.274$ & & -0.034 & & 0.334 & & -0.248 \\
\hline Worker & & $* * 0.235$ & & -0.049 & & 0.399 & & -0.217 \\
\hline \multicolumn{9}{|l|}{ Sector: } \\
\hline Agriculture & & 0.021 & & -0.175 & & 0.033 & & -0.137 \\
\hline Manufacture & & -0.204 & & -0.015 & & 0.003 & & 0.023 \\
\hline Services & & -0.091 & & 0.002 & & -0.129 & & -0.194 \\
\hline Mills Ratio & & & $*-0.286$ & -0.041 & & & $*_{-0.201}$ & $* *-0.365$ \\
\hline Constant & $* *-14.951$ & $* *-24.150$ & $*-24.185$ & -5.829 & $* * 16.475$ & 4.637 & -8.918 & 4.355 \\
\hline No. Observations & 254 & 596 & 377 & 622 & 339 & 321 & 1,462 & 576 \\
\hline Log Likelihood & -50 & -175 & & & -135 & -118 & & \\
\hline Observed participation & 0.609 & 0.238 & & & 0.759 & 0.367 & & \\
\hline Predicted participation & 0.817 & 0.123 & & & 0.822 & 0.226 & & \\
\hline $\mathrm{F}(\mathrm{n}, \mathrm{d})$ & & & $* * 3.6$ & $* * 3.2$ & & & $* * 24.6$ & $* * 2.8$ \\
\hline $\mathrm{R}^{2}$ & & & 0.0859 & 0.1167 & & & 0.0531 & 0.0690 \\
\hline
\end{tabular}

Source: Author's estimates from 1996 CASEN household survey (MIDEPLAN, 1996).

Note: ${ }^{(1)}$ Working hour models for the extreme and moderate poor are jointly estimated, as the separated sample for extreme poor was not sufficiently large for consistent estimation.

(2) Only the preferred version between the linear and non-linear specification form is reported.

Non-labor primary incomes refer to pensions, rents and financial incomes. All elasticities estimated at the mean of all variables in the model. $(*)$ indicates statistical significance at $10 \%$ level; $(* *)$ statistical significance at $5 \%$ level. (M.C.) indicates that the variable is dropped due to multiple collinearity. 


\section{MODERATELY POOR}

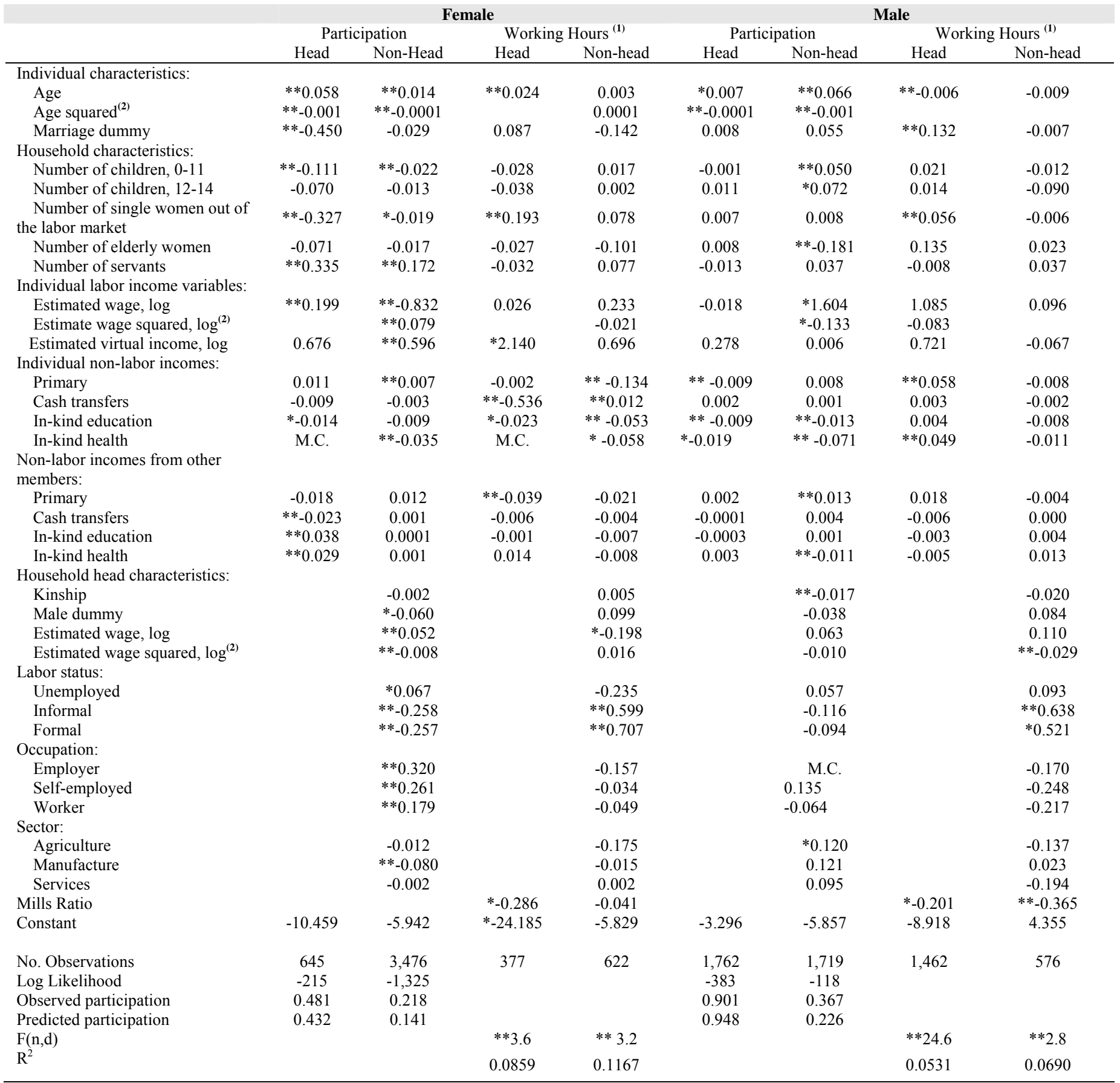

Source: Author's estimates from 1996 CASEN household survey (MIDEPLAN, 1996).

Note: ${ }^{(1)}$ Working hour models for the extreme and moderate poor are jointly estimated, as the separated sample for extreme poor was not sufficiently large for consistent estimation.

(2) Only the preferred version between the linear and non-linear specification form is reported.

Non-labor primary incomes refer to pensions, rents and financial incomes. All elasticities estimated at the mean of all variables in the model. $(*)$ indicates statistical significance at $10 \%$ level; $(* *)$ statistical significance at 5\% level. (M.C.) indicates that the variable is dropped due to multiple collinearity. 
NON-POOR

\begin{tabular}{|c|c|c|c|c|c|c|c|c|}
\hline & \multicolumn{4}{|c|}{ Female } & \multicolumn{4}{|c|}{ Male } \\
\hline & \multicolumn{2}{|c|}{ Participation } & \multicolumn{2}{|c|}{ Working Hours ${ }^{(\mathbf{1})}$} & \multicolumn{2}{|c|}{ Participation } & \multicolumn{2}{|c|}{ Working Hours ${ }^{(\mathbf{1})}$} \\
\hline & Head & Non-Head & Head & Non-head & Head & Non-head & Head & Non-head \\
\hline \multicolumn{9}{|l|}{ Individual characteristics: } \\
\hline Age & $* * 0.047$ & $* * 0.023$ & -0.009 & 0.006 & $* *-0.004$ & $* * 0.003$ & 0.011 & $* *_{-} 0.040$ \\
\hline Age squared ${ }^{(2)}$ & $* *_{-} 0.001$ & $* *_{-} 0.0004$ & & -0.0002 & & & -0.0001 & $* * 0.0005$ \\
\hline Marriage dummy & $* *_{-0} 0.215$ & $* *-0.038$ & -0.038 & 0.007 & $* 0.007$ & 0.017 & 0.011 & 0.017 \\
\hline \multicolumn{9}{|l|}{ Household characteristics: } \\
\hline Number of children, 0-11 & $* *-0.105$ & $* *-0.057$ & -0.007 & -0.001 & 0.001 & $* * 0.023$ & 0.009 & -0.005 \\
\hline Number of children, $12-14$ & $* *_{-} 0.111$ & $* *_{-} 0.065$ & 0.014 & 0.018 & 0.005 & $* *-0.088$ & 0.008 & $* * 0.045$ \\
\hline $\begin{array}{l}\text { Number of single women out of } \\
\text { the labor market }\end{array}$ & $* *-0.535$ & $* *-0.139$ & $* * 0.084$ & 0.031 & 0.004 & -0.013 & $* 0.015$ & $* * 0.032$ \\
\hline Number of elderly women & $* * 0.227$ & $* * 0.070$ & -0.076 & $* *-0.047$ & $* *-0.019$ & -0.036 & -0.027 & -0.019 \\
\hline Number of servants & $* * 0.199$ & $* * 0.271$ & -0.081 & 0.009 & 0.002 & $*_{-0.058}$ & -0.001 & 0.007 \\
\hline \multicolumn{9}{|l|}{ Individual labor income variables: } \\
\hline Estimated wage, log & $* * 0.212$ & $* * 0.221$ & 0.352 & $* * 0.548$ & $* 0.011$ & $* * 0.502$ & $* * 0.466$ & $* * 0.998$ \\
\hline Estimate wage squared, $\log ^{(2)}$ & & & -0.029 & $* *-0.050$ & & & $* *-0.037$ & $* *-0.070$ \\
\hline Estimated virtual income, log & 0.137 & $* *-0.345$ & 0.559 & 0.361 & -0.035 & $* *-3.647$ & 0.044 & $*-0.604$ \\
\hline \multicolumn{9}{|l|}{ Individual non-labor incomes: } \\
\hline Primary & $* *-0.008$ & $* * 0.012$ & -0.004 & $* * 0.021$ & $* *-0.002$ & $* * 0.509$ & 0.00004 & $* * 0.006$ \\
\hline Cash transfers & $* *-0.010$ & $* *-0.004$ & -0.010 & $* * 0.094$ & $* *-0.001$ & $*-0.005$ & -0.003 & $* * 0.005$ \\
\hline In-kind education & $* *-0.016$ & $* * 0-0.010$ & $* *_{-} 0.014$ & -0.005 & $* *-0.003$ & $* *_{-} 0.019$ & -0.003 & 0.004 \\
\hline In-kind health & $* *-0.062$ & $* *-0.034$ & $* *_{-} 0.065$ & $* *-0.063$ & $* *_{-} 0.013$ & $* *-0.079$ & $* * 0.531$ & $* *_{-} 0.048$ \\
\hline \multicolumn{9}{|l|}{$\begin{array}{l}\text { Non-labor incomes from other } \\
\text { members: }\end{array}$} \\
\hline Primary & -0.006 & $* * 0.043$ & -0.003 & $* * 0.054$ & 0.0004 & $* * 0.032$ & 0.003 & $* * 0.045$ \\
\hline Cash transfers & $* *_{-} 0.010$ & -0.002 & -0.008 & -0.003 & $* *-0.002$ & $* *-0.005$ & -0.002 & 0.002 \\
\hline In-kind education & $* * 0.019$ & $* * 0.003$ & -0.003 & -0.003 & 0.0002 & $* * 0.008$ & -0.002 & -0.003 \\
\hline In-kind health & $* * 0.024$ & $* *-0.005$ & -0.001 & $* *-0.005$ & 0.0002 & $* * 0.004$ & -0.001 & -0.001 \\
\hline \multicolumn{9}{|l|}{ Household head characteristics: } \\
\hline Kinship & & 0.001 & & $* *_{-} 0.011$ & & $* *_{-} 0.021$ & & $* *-0.006$ \\
\hline Male dummy & & $* *-0.167$ & & -0.014 & & $* *-0.084$ & & $* * 0.034$ \\
\hline Estimated wage, log & & $* * 0.028$ & & $* * 0.061$ & & $* * 0.131$ & & $* * 0.106$ \\
\hline Estimated wage squared, $\log ^{(2)}$ & & $* *-0.006$ & & $* *-0.011$ & & $* *-0.021$ & & $* *-0.017$ \\
\hline \multicolumn{9}{|l|}{ Labor status: } \\
\hline Unemployed & & $* * 0.182$ & & -0.042 & & $* * 0.137$ & & -0.005 \\
\hline Informal & & $*-0.083$ & & 0.058 & & 0.085 & & 0.041 \\
\hline Formal & & $*_{-} 0.006$ & & 0.069 & & 0.206 & & 0.074 \\
\hline \multicolumn{9}{|l|}{ Occupation: } \\
\hline Employer & & $* * 0.251$ & & 0.063 & & -0.006 & & $* * 0.121$ \\
\hline Self-employed & & $* * 0.212$ & & 0.041 & & -0.011 & & 0.031 \\
\hline Worker & & $* * 0.169$ & & -0.131 & & -0.089 & & -0.041 \\
\hline \multicolumn{9}{|l|}{ Sector: } \\
\hline Agriculture & & $* *-0.034$ & & 0.001 & & $* * 0.205$ & & -0.004 \\
\hline Manufacture & & $* *-0.038$ & & -0.002 & & 0.031 & & -0.024 \\
\hline Services & & 0.005 & & -0.027 & & $* *-0.085$ & & 0.022 \\
\hline Mills Ratio & & & -0.067 & -0.062 & & & 0.017 & $* *-0.471$ \\
\hline Constant & -3.234 & 2.394 & 10.057 & -3.144 & 0.699 & $* * 43.117$ & 1.526 & $* 8.351$ \\
\hline No. Observations & 5,410 & 34,965 & 2,178 & 10,062 & 20,932 & 18,169 & 17,860 & 8,571 \\
\hline Log Likelihood & $-1,792$ & $-16,081$ & & & $-3,795$ & $-6,732$ & & \\
\hline Observed participation & 0.461 & 0.348 & & & 0.897 & 0.504 & & \\
\hline Predicted participation & 0.389 & 0.261 & & & 0.970 & 0.440 & & \\
\hline $\mathrm{F}(\mathrm{n}, \mathrm{d})$ & & & $* * 2.5$ & $* * 5.3$ & & & $* * 4.0$ & $* * 5.6$ \\
\hline $\mathrm{R}^{2}$ & & & 0.0407 & 0.0573 & & & 0.0531 & 0.1017 \\
\hline
\end{tabular}

Source: Author's estimates from 1996 CASEN household survey (MIDEPLAN, 1996).

Note: ${ }^{(1)}$ Working hour models for the extreme and moderate poor are jointly estimated, as the separated sample for extreme poor was not sufficiently large for consistent estimation.

(2) Only the preferred version between the linear and non-linear specification form is reported.

Non-labor primary incomes refer to pensions, rents and financial incomes. All elasticities estimated at the mean of all variables in the model. $(*)$ indicates statistical significance at $10 \%$ level; $(* *)$ statistical significance at $5 \%$ level. 


\section{REFERENCES}

Ashenfelter, O., and J.J. Heckman. 1974. The estimation of incomes and substitution effects in a model of family labour supply. Econometrica 42, 73--85.

Blumberg, R.L. 1988. Income under female versus male control: hypothesis from a theory of gender stratification and data from the Third World. Journal of Family Issues 9, 51--84.

Browning, M., F. Bourguignon, P.A. Chiappori and V. Lechéne. 1994. Income and outcomes: a structural model of intrahousehold allocation. Journal of Political Economy 102, 1067--96.

Casique, M. 2000. Mexican married women's autonomy and power within the household. Paper presented at the Latin American Studies Association, Rio de Janeiro, January 2000.

Chiappori, P.A. 1997. "Collective" models of household behaviour: the sharing rule approach, in Haddad, L., Hoddinott, J., Alderman, H (Eds.) Intrahousehold Resource Allocation in Developing Countries: Models, Methods and Policy. Baltimore: The Johns Hopkins University Press.

Floro, M.S. 1995. Economic restructuring, gender and the allocation of time. World Development 23, 1913--29.

Garfinkel, I., P.K. Robbins, J.B. Shoven, and D.R. Meyer. 1990. The Wisconsin Child Support Assurance system: estimated effects on poverty, labour supply, caseloads and costs. Journal of Human Resources 25, 1--31.

Hausman, J.A. 1985. The Econometrics of Nonlinear Budget Sets. Econometrica 53 (6): 1255-82.

Heckman, J. J. 1979. Sample selection bias as a specification error. Econometrica 47, 153--62.

INTEGRA. 1998. Informe sobre el Presupuesto y Costo Día Niño. Santiago de Chile: Fundación INTEGRA.

Jejeebhoy, S. J. 1995. Women's Education, Autonomy, Reproductive Behaviour: Experience from Developing Countries. Oxford: Clarendon Press.

Junta Nacional de Ayuda Escolar y Becas (JUNAEB).1998. Programas Asistenciales 1997/1998. Santiago de Chile: JUNAEB.

Junta Nacional de Jardines Infantiles (JUNJI). 1998. Programas 1998. Santiago de Chile: JUNJI.

Juster, F.T. and F.P. Sttaford. 1991. The allocation of time: empirical findings, behavioural models and problems of measurement. Journal of Economic Literature 29, 471--522.

Killingsworth, M. 1983. Labour Supply. Cambridge: Cambridge University Press.

Killingsworth, M. and J. J. Heckman. 1986. Female labour supply: a survey, in Ashenfelter, O. and R. Layard (Eds.) Handbook of Labour Economics, vol. 1, New York: North-Holland, pp. 103--204.

Leuthold, J. 1968. An empirical analysis of the formula resource transfers and the work decision of the poor. Journal of Economic Resources 3, 312-23.

Licona, G. 1997. Oferta labour al familiar y desempleo en México. Los efectos de la pobreza. El Trimestre Económico 64, 531--68.

Millán I, D. Contreras and D. Bravo. 1999. Impacto distributivo del gasto social sobre la distribución de ingresos en Chile. Master's Thesis. Universidad de Chile.

Ministerio de Desarrollo y Planificación (MIDEPLAN). 2000. Indicadores Económicos y Sociales 1990-1998.Evolución de la Pobreza e Indigencia. Santiago de Chile: MIDEPLAN.

Ministerio de Desarrollo y Planificación (MIDEPLAN). 1996. CASEN 1996 Household Survey. Santiago de Chile: MIDEPLAN

Ministerio de Educación (MINEDUC). 1996. Compendio de Información Estadística. Santiago de Chile: MINEDUC.

Ministerio de Salud (MINSAL). 1999. Anuario de Atenciones y Recursos, 1996. Santiago de Chile: MINSAL.

Pahl, J. 1989. Money and Marriage. London: Macmillan.

Rao, V. 1997. Wife-beating in rural South India: a qualitative and econometric analysis. Social Science and Medicine 44, 1169--80.

Rubalcava, L. and D. Contreras. 1999. Does gender and birth matter when parents specialise on child's nutrition? Evidence from Chile. Santiago de Chile: Dept. of Economics, U. de Chile.

Schultz, T. P. 1990. Testing the neoclassical model of family labour supply and fertility. Journal of Human Resources 25, 599--634.

Selowsky, M. 1979. Who Benefits from Government Expenditure? A Case Study of Colombia. New York: Oxford University Press.

Stern, N. 1984. On the specification of labour supply functions, in Blundel, R.W., Walker, I. (Eds.), Unemployment, Search and Labour Supply. Cambridge: Cambridge University Press.

Superintendencia de la Seguridad Social. 1996. Boletines. Santiago de Chile. Superintendencia de la Seguridad Social.

World Bank. 1997. Chile: Poverty and Income Distribution in a High-Growth Economy: 1987-1995. World Bank Report No. 16377-CH, vol. 2. Washington DC: World Bank 
Table 1. Predicted Effects of Social Transfers in the Intrahousehold Decision to Work

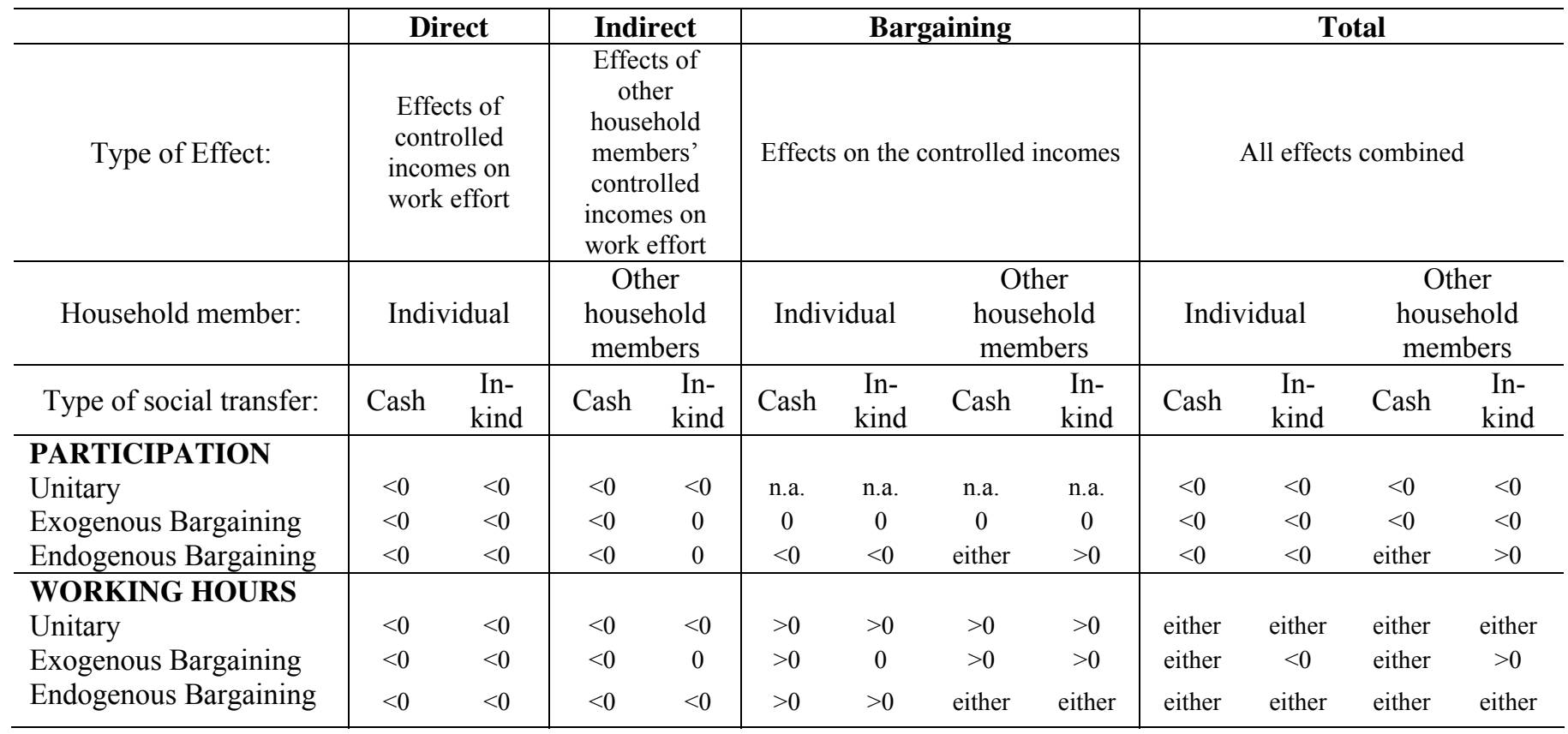

Source: Author

Note: unitary models predicted effects are calculated assuming that equal bargaining power among household members, that is, $\theta_{\mathrm{i}}=1 / \mathrm{n}$, where $\mathrm{n}$ is the number of members in a household. 'n.a.', not applicable.

Table 2. Tests on Intrahousehold Behavior

\begin{tabular}{cccc}
\hline Mnitary Household & $\begin{array}{c}\text { Exogenous } \\
\text { Model }\end{array}$ & $\begin{array}{c}\text { Endogenous } \\
\text { Bargaining Model } \\
\text { with social transfers } \\
\text { as determinants }\end{array}$ \\
\hline $\mathbf{H}_{\mathbf{0}}:$ & $\gamma_{5 i}<0$ & $\gamma_{5 i}<0$ & $\gamma_{5 i}<0$ \\
& $\gamma_{6 i}<0$ & $\gamma_{6 i}<0$ & $\gamma_{6 i}<0$ \\
& $\gamma_{7 i}<0$ & $\gamma_{7 i}<0$ & $\gamma_{7 i}<0$ \\
& $\gamma_{9 i}<0$ & $\gamma_{9 i}<0$ & $\gamma_{10 i}>0$ \\
& $\gamma_{10 i}<0$ & $\gamma_{10 i}=0$ & $\gamma_{11 i}>0$ \\
& $\gamma_{11 i}<0$ & $\gamma_{11 i}=0$ & \\
& & & \\
& & & otherwise \\
\hline
\end{tabular}

Source: Author

Note: tests defined over participation elasticities in specification (1) 
Table 3. Participation and Working Hour Elasticities of Non-labor Incomes

\begin{tabular}{|c|c|c|c|c|c|c|c|c|c|}
\hline & & \multicolumn{4}{|c|}{ Female } & \multicolumn{4}{|c|}{ Male } \\
\hline & & \multicolumn{2}{|c|}{ Participation } & \multicolumn{2}{|c|}{ Working Hours } & \multicolumn{2}{|c|}{ Participation } & \multicolumn{2}{|c|}{ Working Hours } \\
\hline & & Head & $\begin{array}{l}\text { Non- } \\
\text { Head }\end{array}$ & Head & $\begin{array}{l}\text { Non- } \\
\text { head }\end{array}$ & Head & $\begin{array}{l}\text { Non- } \\
\text { head }\end{array}$ & Head & $\begin{array}{l}\text { Non- } \\
\text { head }\end{array}$ \\
\hline All non-labor incomes & & $* *-3.60$ & $* 0.58$ & -0.37 & 0.08 & $* *_{-}-0.30$ & $* *-4.96$ & 0.02 & $* *-0.62$ \\
\hline $\begin{array}{l}\text { All individual non-labor } \\
\text { incomes }\end{array}$ & & $* *-4.31$ & 0.02 & -0.33 & -0.03 & $* *-0.38$ & $* *-5.32$ & $* *-0.16$ & $* * 0.63$ \\
\hline $\begin{array}{l}\text { All non-labor from other } \\
\text { household members }\end{array}$ & & -0.99 & $* * 19.02$ & -0.63 & $* * 5.23$ & $* * 0.18$ & $* * 6.51$ & 0.18 & $* * 4.16$ \\
\hline $\begin{array}{l}\text { Individual non-labor } \\
\text { incomes: }\end{array}$ & & & & & & & & & \\
\hline Primary & $\gamma_{4}$ & $* * 1.34$ & $* * 8.98$ & 0.32 & 0.23 & $* *-0.31$ & $* * 1.25$ & $* * 0.26$ & $* * 0.67$ \\
\hline Cash transfers & $\gamma_{5}$ & $* *-2.06$ & $* * 9.87$ & $*-1.09$ & $*_{-}-0.67$ & -0.09 & $* *-1.07$ & $* *-1.67$ & $* * 0.47$ \\
\hline In-kind education & $\gamma_{6}$ & $* *-4.09$ & $* *-3.97$ & $* *-1.49$ & $*_{-0.74}$ & $* *-0.45$ & $* *-4.85$ & -0.14 & 0.35 \\
\hline In-kind health & $\gamma_{7}$ & $* *-1.37$ & $* *-14.37$ & $* *_{-} 6.62$ & $* *-6.19$ & $* *-1.79$ & **-18.36 & 0.49 & $* *-4.58$ \\
\hline $\begin{array}{l}\text { Non-labor incomes from } \\
\text { other household } \\
\text { members: }\end{array}$ & & & & & & & & & \\
\hline Primary & $\gamma_{8}$ & -1.37 & $* * 15.71$ & -1.05 & $* * 4.29$ & $* * 0.13$ & $* * 8.57$ & 0.04 & $* * 4.75$ \\
\hline Cash transfers & $\gamma_{9}$ & $* *-0.28$ & -0.59 & -0.81 & $*_{-}-0.42$ & $* *_{-}-0.26$ & $* *-1.14$ & $* *_{-}-0.20$ & 0.14 \\
\hline In-kind education & $\gamma_{10}$ & $* * 5.28$ & -1.02 & 0.31 & $*_{-0.37}$ & 0.02 & $* * 1.51$ & -0.02 & -0.23 \\
\hline In-kind health & $\gamma_{11}$ & $* * 5.77$ & $* * 1.89$ & 0.18 & $* *-0.61$ & 0.07 & $* 0.39$ & $* 0.14$ & -0.04 \\
\hline No. Observations & & 6,370 & 39,919 & 2,573 & 10,884 & 23,461 & 20,797 & 19,546 & 9,485 \\
\hline Log Likelihood & & $-2,129$ & $-10,512$ & & & $-4,678$ & $-7,828$ & & \\
\hline Observed participation & & 0.465 & 0.335 & & & 0.891 & 0.501 & & \\
\hline Predicted participation & & 0.401 & 0.247 & & & 0.96 & 0.431 & & \\
\hline $\mathrm{F}(\mathrm{n}, \mathrm{d})$ & & & & $* * 3.0$ & $* * 5.5$ & & & $* * 7.7$ & $* * 6.1$ \\
\hline $\mathrm{R}^{2}$ & & & & 0.0457 & 0.0480 & & & 0.0126 & 0.0939 \\
\hline
\end{tabular}

Source: Author's estimates from 1996 CASEN household survey (MIDEPLAN, 1996).

Note: Non-labor primary incomes refer to pensions, rents, financial incomes and self-consumption. All elasticities estimated at the mean of all variables in the model. $(*)$ indicates statistical significance at $10 \%$ level; $(* *)$ statistical significance at $5 \%$ level.

Table 4. Tests on the Specification of Intrahousehold Allocation Models

\begin{tabular}{l|cc|cc} 
& \multicolumn{2}{|c|}{ Female } & \multicolumn{2}{c}{ Male } \\
& Head & Non-head & Head & Non-head \\
\hline Unitary household model & $\mathrm{H}_{\mathrm{o}}$ Rejected & $\mathrm{H}_{\mathrm{o}}$ Rejected & $\mathrm{H}_{\mathrm{o}}$ Rejected & $\mathrm{H}_{\mathrm{o}}$ Rejected \\
Exogenous Bargaining Model & $\mathrm{H}_{\mathrm{o}}$ Rejected & $\mathrm{H}_{\mathrm{o}}$ Rejected & $\mathrm{H}_{\mathrm{o}}$ Rejected & $\mathrm{H}_{\mathrm{o}}$ Rejected \\
Endogenous Bargaining Model with & $\mathrm{H}_{\mathrm{o}}$ Accepted & $\mathrm{H}_{\mathrm{o}}$ Accepted & $\mathrm{H}_{\mathrm{o}}$ Rejected & $\mathrm{H}_{\mathrm{o}}$ Accepted \\
Social Transfers as determinants & & & \\
\hline
\end{tabular}

Source: Author

Note: tests from estimated elasticities of participation in specification [1]. 
Table 5. Tests on the Specification of Intrahousehold Allocation Models By Socio-economic Group

\begin{tabular}{|c|c|c|c|c|c|c|}
\hline & \multicolumn{3}{|c|}{ Exogenous Bargaining Model } & \multicolumn{3}{|c|}{$\begin{array}{c}\text { Endogenous Bargaining Model with Social } \\
\text { Transfers as Determinants }\end{array}$} \\
\hline & $\begin{array}{l}\text { Extreme } \\
\text { Poor }\end{array}$ & $\begin{array}{l}\text { Moderate } \\
\text { Poor }\end{array}$ & Non-Poor & $\begin{array}{l}\text { Extreme } \\
\text { Poor }\end{array}$ & $\begin{array}{l}\text { Moderate } \\
\text { Poor }\end{array}$ & Non-Poor \\
\hline Female Head & $\mathrm{H}_{\mathrm{o}}$ Rejected & $\mathrm{H}_{\mathrm{o}}$ Rejected & $\mathrm{H}_{\mathrm{o}}$ Rejected & $\mathrm{H}_{\mathrm{o}}$ Rejected & $\mathrm{H}_{\mathrm{o}}$ Rejected & $\mathrm{H}_{\mathrm{o}}$ Accepted \\
\hline Female Non-head & $\mathrm{H}_{\mathrm{o}}$ Rejected & $\mathrm{H}_{\mathrm{o}}$ Rejected & $\mathrm{H}_{\mathrm{o}}$ Rejected & $\mathrm{H}_{\mathrm{o}}$ Rejected & $\mathrm{H}_{\mathrm{o}}$ Rejected & $\mathrm{H}_{\mathrm{o}}$ Accepted \\
\hline Male Head & $\mathrm{H}_{\mathrm{o}}$ Rejected & $\mathrm{H}_{\mathrm{o}}$ Rejected & $\mathrm{H}_{\mathrm{o}}$ Accepted & $\mathrm{H}_{\mathrm{o}}$ Rejected & $\mathrm{H}_{\mathrm{o}}$ Rejected & $\mathrm{H}_{\mathrm{o}}$ Rejected \\
\hline Male Non-head & $\mathrm{H}_{\mathrm{o}}$ Rejected & $\mathrm{H}_{\mathrm{o}}$ Rejected & $\mathrm{H}_{\mathrm{o}}$ Rejected & $\mathrm{H}_{\mathrm{o}}$ Rejected & $\mathrm{H}_{\mathrm{o}}$ Rejected & $\mathrm{H}_{\mathrm{o}}$ Accepted \\
\hline
\end{tabular}

Source: Author

Note: tests from estimated elasticities of participation in specification [1]. 